\title{
Qualitative HPLC-DAD-ESI-TOF-MS analysis, cytotoxic and apoptotic effects of Croatian endemic Centaurea ragusina L. aqueous extracts
}

\author{
Mila Radan, ${ }^{\text {a)* }}$ Ivana Carev, ${ }^{\text {a) }}$ Vele Tešević, ${ }^{\text {b) }}$ Olivera Politeo ${ }^{\text {a) }}$ and Vedrana Čikeš Čulićc \\ ${ }^{a}$ Faculty of Chemistry and Technology, University of Split, Ruđera Boškovića 35, 21000 Split, Croatia. \\ ${ }^{\mathrm{b}}$ Faculty of Chemistry, University of Belgrade, Studentski trg 12-16, 11158 Belgrade, Serbia

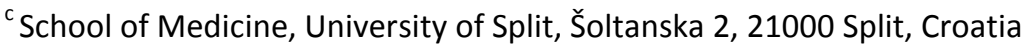

*Author to whom correspondence should be addressed: Email: mradan@ktf-split.hr;

Tel.: +38598436556

\section{Abstract}

Centaurea ragusina L., an endemic Croatian plant species, revealed a good cytotoxic activity of aqueous extracts on human bladder (T24) and human glioblastoma (A1235) cancer cell lines. The chemical constituents were tentatively identified using high performance liquid chromatography HPLC-DAD-ESI-TOF-MS in negative ionization mode. The main compounds of herba extract were sesquiterpene lactones: solstitialin A-3, 13 diacetate and epoxyrepdiolide; organic acid: quinic acid. The main compounds of flower extract were organic acids: quinic acid, citric acid and malic acid; sesquiterpene lactone: cynaropicrin; phenolic compounds: chlorogenic acid and phenylpropanoid: syringin. The aqueous extracts of $C$. ragusina were investigated for correlation of their effects on This article has been accepted for publication and undergone full peer review but has not been through the copyediting, typesetting, pagination and proofreading process, which may lead to differences between this version and the Version of Record. Please cite this article as doi: 10.1002/cbdv.201700099

This article is protected by copyright. All rights reserved. 
human bladder (T24) and human glioblastoma (A1235) cancer cell lines using the MTT assay. Although both extracts showed significant dose- and time-dependent cytotoxic activity against both cancer cell lines, the flower extract exhibited slightly higher activity. In order to determine type of cell death induced by treatment, cell lines were exposed subsequently to a treatment with both flower and herba aqueous extracts. The majority of the cells died by induced apoptosis treatment. Flower aqueous extract $(26.25 \%)$, compared to a leaf aqueous extract $(22.15 \%)$ showed slightly higher percentage of an apoptosis in T24 cells, when compared to a non-treated cells (0.04 \%).

Keywords: Centaurea ragusina; cytotoxic; apoptotic; MTT; sesquiterpene lactone

\section{Introduction}

Plants natural products, over a long historical period, have been used as chemo-protective agents in cancer treatment ${ }^{[1,2]}$. Natural products may not necessarily be the final drug compound, but may serve as sources of novel structures for a final anticancer medicine. Over the time period of more than 70 years, $48.6 \%$ of 175 small molecules, used in cancer treatment, are either natural products or directly derived from natural products ${ }^{[1]}$. Some of the current anticancer drugs derived from plant extracts belong to a group of terpenes ${ }^{[3]}$. Centaurea species are rich in terpene compounds, mainly sesquiterpenes, and are a good potential source of cytotoxic compounds that may serve as an anticancer drug ${ }^{[4,5]}$. Asteraceae species are well known in many bioactive compounds, although there are still many species where the biological activity of their extracts has not yet been investigated $^{[6,7]}$.

Centaurea genus is one of the largest in the Asteraceae family, comprising around 400-700 species, distributed mainly in the Mediterranean area ${ }^{[8]}$. In Croatia, there are more than 80 Centaurea species with 27 endemics ${ }^{[9]}$. C. ragusina, Dubrovnik's cornflower or dusty miller, is an endemic Croatian plant species growing in a very small geographic area, in the arid and salt-affected gaps of the vertical cliffs along the Adriatic coast and Croatian islands.

This article is protected by copyright. All rights reserved. 
The species which belong to Centaurea genus possess a valuable source of bioactive compounds and have been used in ethno-medicines throughout Europe, especially in the Mediterranean region ${ }^{[7,10-}$ ${ }^{14]}$. The wild growing Centaurea plants have been traditionally used for treatment of various diseases due to their antimicrobial, antifungal, anti-inflammatory, antidiabetic, antioxidant, antiviral, antitumor and other properties ${ }^{[10-12,15]}$.

Cytotoxic properties of the Centaurea plant extracts are usually related to their chemical composition. The majorities of compounds in aqueous extracts (AE) belong, but are not limited to the groups of sesquiterpene lactones (SQLS), acetylenes, phenolics, flavonoids, glycosides, lignans, coumarines and others ${ }^{[16-21]}$. Sesquiterpene lactones, phenols, flavonoids and lignans are usually regarded as a group of compounds responsible for diverse biological activity of Centaurea plant extracts ${ }^{[15,16,22]}$.

The majority of the Centaurea species have not yet been investigated on the phytochemical profile and biological activity of their extracts ${ }^{[23]}$.

Previous research on C. ragusina species studied phytochemical composition of volatile compounds and its efficient antimicrobial effects ${ }^{[24]}$ as well as total polyphenol content and antioxidant activity of plant specimens cultivated in vitro and collected in natural habitats ${ }^{[25]}$.

The medicinal importance and diverse biological activity of Centaurea genus species motivated us to study the biological activity of $C$. ragusina AE. To our best knowledge, no data on phytochemical studies of $C$. ragusina $A E$ have been available to date. This study aims to evaluate the cytotoxic activity and phytochemical profile of AE obtained from endemic Croatian species $C$. ragusina.

\section{Results and discussion}

\section{Phytochemical profile of the aqueous extracts of $C$. ragusina}

C. ragusina herba and flower AE phytochemical profile was studied using HPLC-DAD-ESI-TOF-MS system. Results are presented as chromatographs (Fig. 1) and list of determined chemical compounds (Table 1.). The detected compounds were all tentatively identified by comparison of their spectroscopic data with data reported in the literature and by correlation with previous literature reports.

This article is protected by copyright. All rights reserved. 

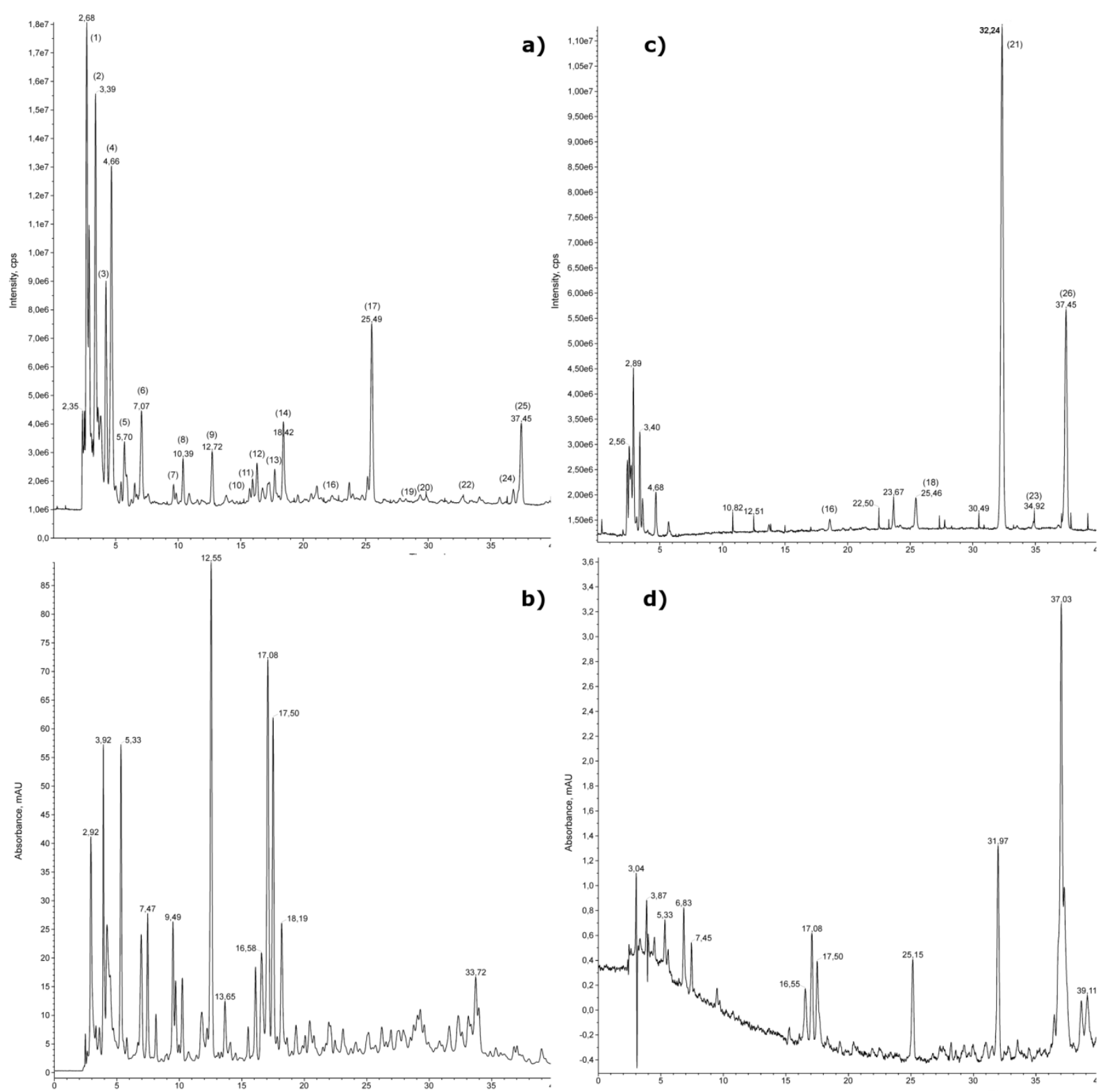

Figure 1: The TIC chromatogram of negative mode (a) and HPLC-DAD chromatogram of Centaurea ragusina L. flower aqueous extract (b); the TIC chromatogram of negative mode (c) and HPLC-DAD chromatogram of Centaurea ragusina L. herba aqueous extract (d)

This article is protected by copyright. All rights reserved. 
Table 1. Tentative assignment of chemical components found in herba and flower of Centaurea ragusina $\mathrm{L}$. aqueous extracts by using HPLC-DAD-ESI-TOF-MS in negative ionization mode.

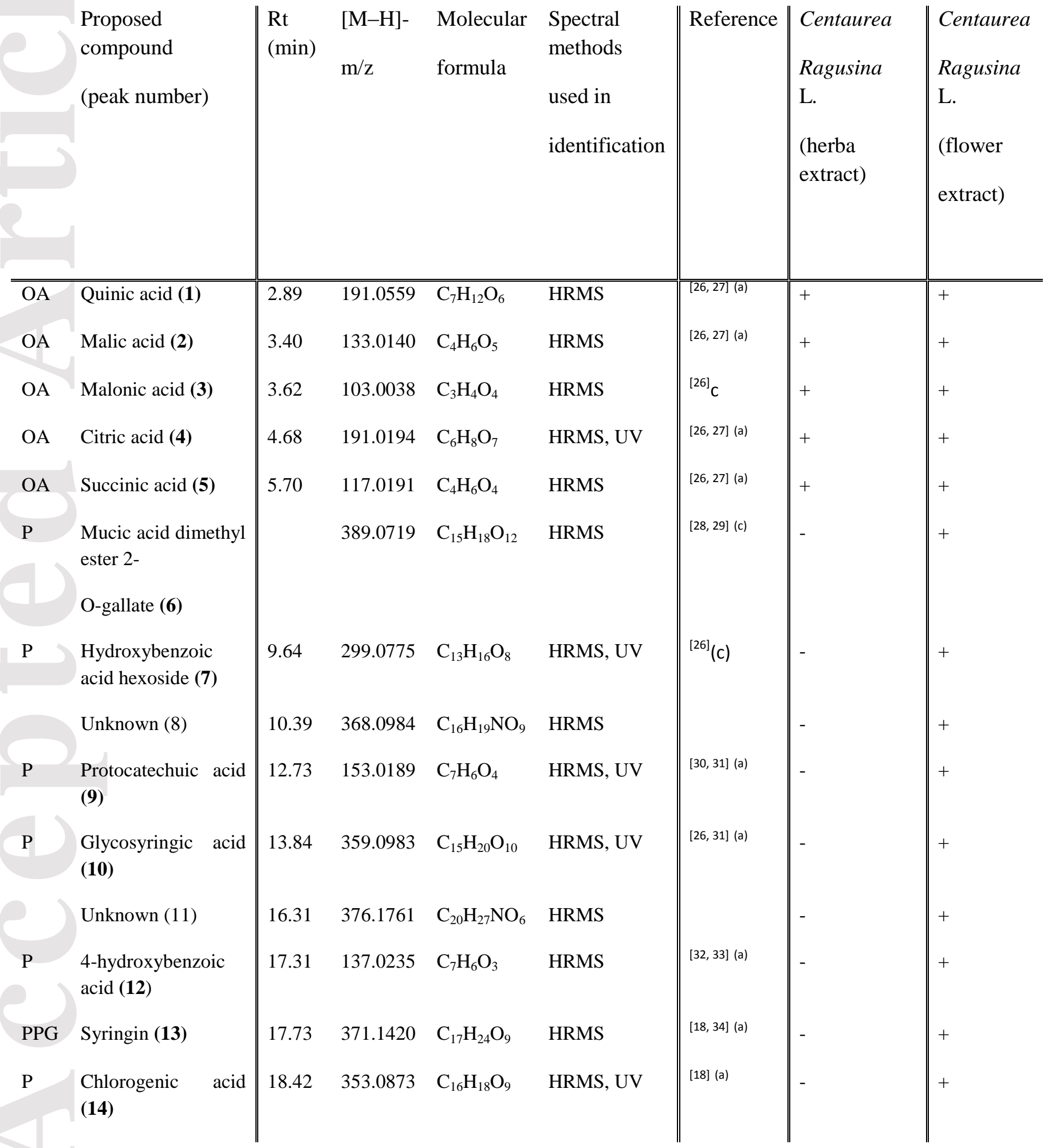

This article is protected by copyright. All rights reserved. 


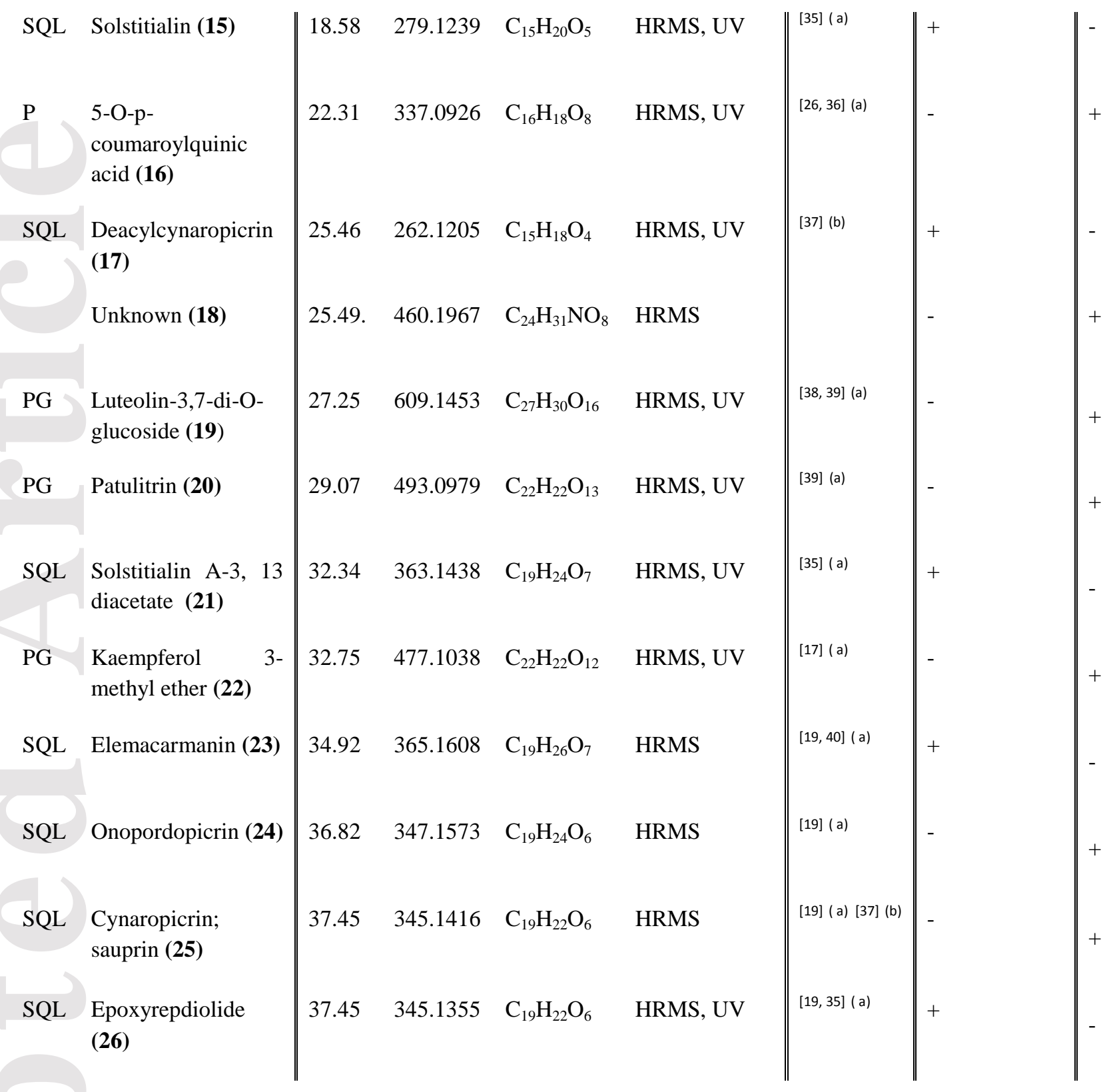

HPLC-DAD-ESI-TOF-MS: High performance liquid chromatography-diode array detector-electrospray ionization-time of flight-mass spectrometry; $[\mathrm{M}-\mathrm{H}]^{-} \mathrm{m} / \mathrm{z}$-deprotonated ion mass-to-charge ratio.

Identification was supported by comparison of their spectroscopic data with those reported in the literature: ${ }^{(a)}$ known constituents of other Centaurea species; ${ }^{(b)}$ compound already reported as constituents of $C$. ragusina; ${ }^{\left({ }^{(c)}\right.}$ not reported in the genus Centaurea before

Compound class: OA -organic acid, SQL-sesquiterpene lactone, PPG-phenylpropane glucosides, Pphenolic, PG- flavonoid glycoside; peak numbers and retention times (RT) refer to HPLC chromatograms in Figure 1.

This article is protected by copyright. All rights reserved. 
The main compounds in herba AE were SQLs: solstitialin A-3, 13 diacetate and epoxyrepdiolide; quinic acid as organic acid. The main compounds in flower AE were organic acids: quinic acid, citric acid, malic acid; SQLs cynaropicrin; phenolic compounds chlorogenic acid and phenylpropanoid syringin.

Herba and flower AE have different chemical compositions. The main difference is that phenolic compounds are not found in herba AE. Flower AE contains three flavonoid compounds: luteolin-3,7di-O glucoside, patulitrin and kaempferol 3-methyl ether and two SQLs, cynaropicrin and onopordopicrin, which are absent in the herba AE.

Chemical composition of herba AE contains SQLs solstitialin A-3, 13 diacetate and epoxyrepdiolide, together with three SQLs identified in herba AE only: solstitialin, deacylcynaropicrin, elemacramanin. It is important to say that SQLS are a typical group of compounds present in the Asteraceae family [41].

Among detected chemical compounds in flower extract three unknown nitrogen containing compounds were found. This may imply the presence of alkaloid compounds. There are some known alkaloid compounds detected in Centaurea species, however there is no data on the presence of nitrogen containing compounds in Centaurea species detected in the present study ${ }^{[36]}$.

Diversity of phytochemicals in Centaurea species is connected with environmental conditions and germination stage as is the common case with the plants. It is also connected with a plant response to an environment and natural enemies ${ }^{[42]}$. The specific phytochemicals present in plants may have implications for the conservation of the species. In the context of Centaurea ragusina, Croatian endemic species this may be considered as well.

\section{Anti-proliferative activity of $C$. ragusina aqueous extracts}

Cytotoxic activity of herba and flower AE of $C$. ragusina was tested on human glioblastoma (A1235) and human bladder cancer (T24) cell lines after 4 h, 24 h, 48 h and 72 h treatment, using the MTT assay.

This article is protected by copyright. All rights reserved. 
Both C. ragusina flower and herba $A E$ showed a dose- and time-dependent cytotoxic activity against both tested cell lines. The flower AE showed better cytotoxic activity on both cell lines using all concentrations.

After $24 \mathrm{~h}$ treatment with both, flower and herba $A E$, in concentrations of $2 \mathrm{~g} / \mathrm{L}$ and $1 \mathrm{~g} / \mathrm{L}$, cells viability decreased below $15 \%$ and $25 \%$ respectively, compared to non-treated cells (100\% of viability, cell survival =1, Fig. 2).

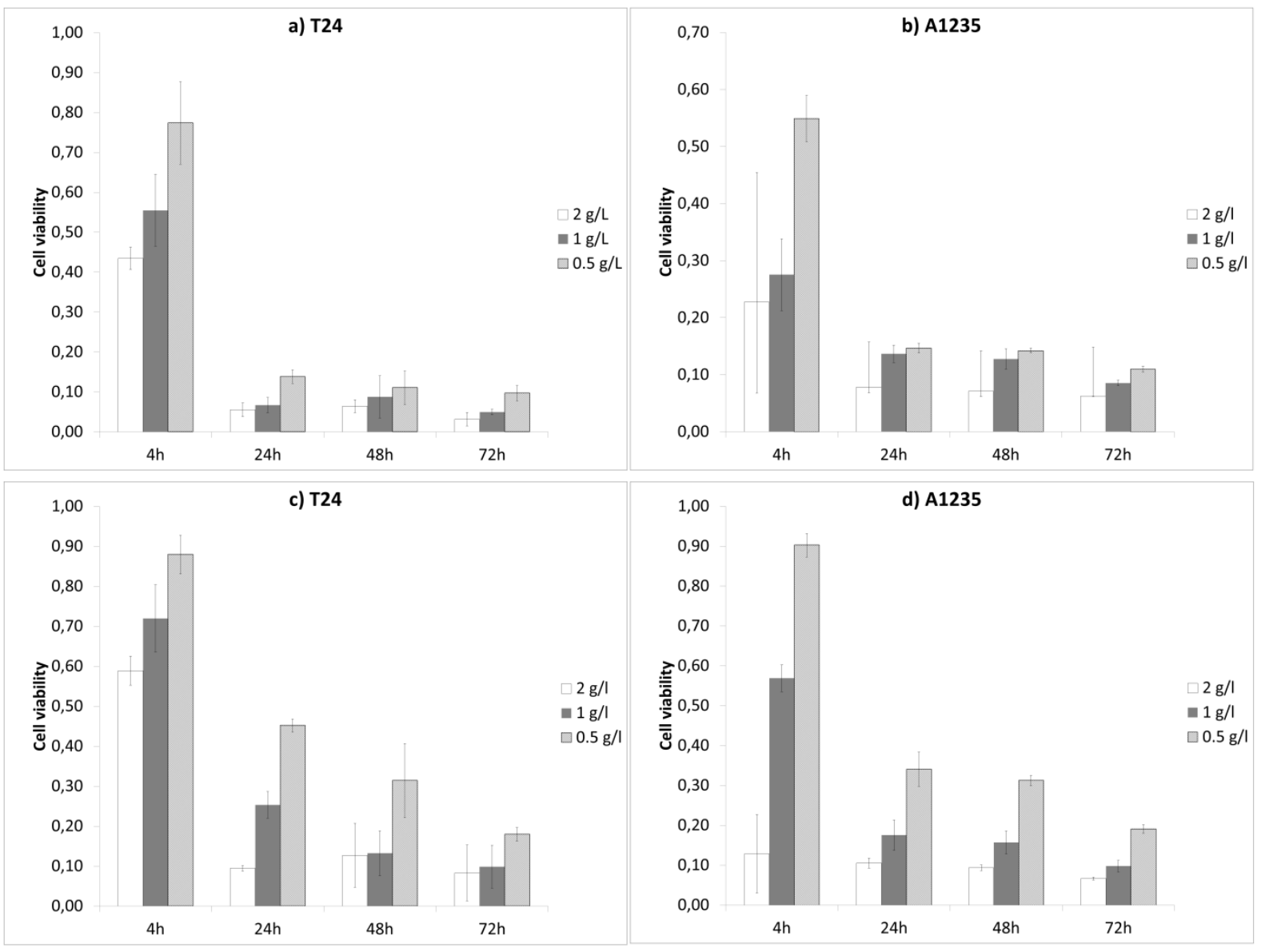

Figure 2. Dose-time response effect of Centaurea ragusina L. flower aqueous extract on human bladder (a) and human glioblastoma (b) cancer cell lines and herba aqueous extract on human bladder (c) and human glioblastoma (d) cancer cell lines using the MTT assay.

This article is protected by copyright. All rights reserved. 
The flower AE expressed a significant cytotoxic activity toward both cell lines with very small difference in concentration-dependent activity after $24 \mathrm{~h}, 48 \mathrm{~h}$, and $72 \mathrm{~h}$ treatment.

The results indicate that, after $72 \mathrm{~h}$ treatment, both flower and herba AE significantly inhibit cell proliferation in a concentration-dependent manner. The flower AE had a higher effect compared to herba AE. At concentration of 0.5 and $1.0 \mathrm{~g} / \mathrm{L}$, it inhibited the cell growth by $65.5 \pm 2.4 \%(P<0.01)$ and $93.1 \pm 0.4 \%(P<0.01)$, respectively.

\section{The extracts induced cell death of T24 cells occurs mainly by apoptosis}

Type of the cell death was determined using the $48 \mathrm{~h}$ treatment with $1 \mathrm{~g} / \mathrm{L}$ of the both, flower and herba $\mathrm{AE}$; of $\mathrm{T} 24$ bladder cancer cells ${ }^{[43,44]}$.

The majority of the cells died by treatment induced apoptosis (Fig. 3). Flower extract (26.25\%) compared to a leaf extract (22.15\%) showed slightly higher percentage of an apoptosis in T24 cells compared to non-treated cells (0.04\%).

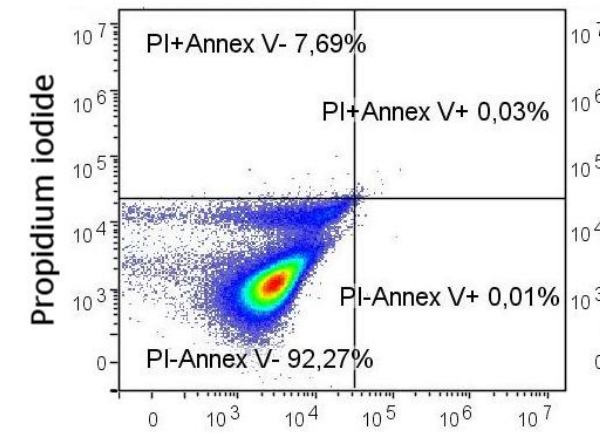

a)

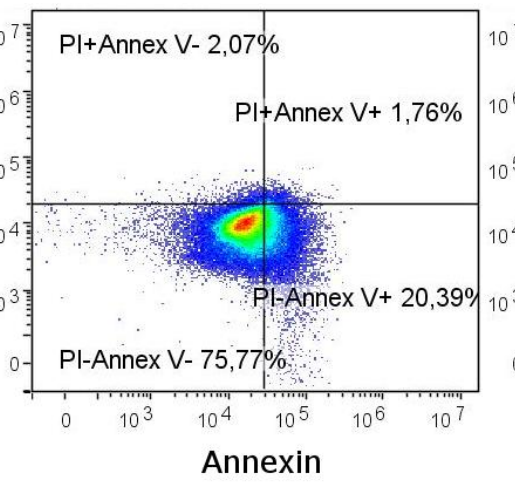

b)

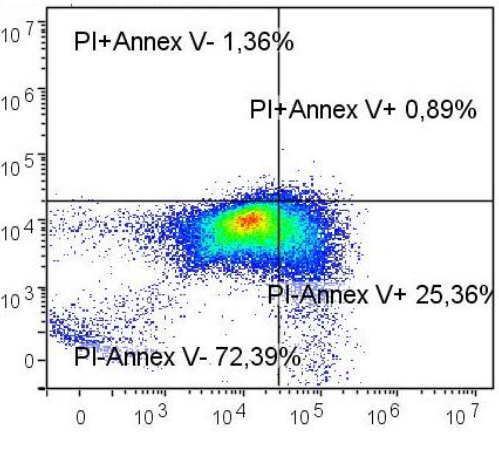

c)

Figure 3: Apoptosis after treatment with $1 \mathrm{mg} / \mathrm{mL}$ Centaurea ragusina L. flower (b) and herba aqueous (c) extract in duration of $48 \mathrm{~h}$ in T24 cell lines in comparison to nontreated cells (a).

This article is protected by copyright. All rights reserved. 
Previous studies of the genus Centaurea revealed that aqueous extracts of some Centaurea species show cytotoxic activity on human cell lines ${ }^{[15,22,45-55]}$. Sesquiterpene lactones, a group of chemical compounds typical for Asteraceae family, are well known on their wide spectrum of biological activities including cytotoxic activities ${ }^{[41,56]}$. A common feature of SQLs that result in their strong biological activity is the presence of the $\alpha$-methylene- $\gamma$-lactone ring, a $\beta$-unsaturated cyclopentenone ring or $\alpha$-epoxycyclopentenone system. The mode of action of SQLs includes quick reaction with thiols such as cysteine by rapid Michael-type addition. This way SQLs inhibit tumor growth by controlling cell division reacting with thiol group in key enzymes in this process. Other mode of reaction in tumor inhibition includes inhibition of sulphydryl enzymes, phosphofructokinases and glycogen synthase activities ${ }^{[41,57]}$. Sesquiterpene lactones also react with DNA polymerases, thymidylate synthase as well as ribosomal polymerase and mitochondrial energy processes. ${ }^{[41]}$. Sesquiterpene lactones are generally known to impair the activity of the NF-KB transcription factor ${ }^{[56]}$. In the case of activity of Centaurea omphalotricha sesquiterpene lactones on the growth of the human leukemia cell lines, study revealed that the presence of exocyclic, conjugated double bond is essential for the cytotoxic activity against HL-60 and U937 cells determined by MTT test ${ }^{[46]}$.

Syringin, phenylpropanoid glycoside, showed diverse pharmacological properties including cytotoxicity ${ }^{[58]}$ against MCF-7, HeLa and Du145 cancer cell line. It showed no apoptotic effect in cell cycle analysis but DNA fragmentation study revealed necrosis as cytotoxic effect ${ }^{[59]}$. Cynaropicrin has been reported to possess immunomodulatory effects on cytokine release, nitric oxide production and immunosuppressive effects ${ }^{[22]}$. Cynaropicrin and deacylcynaropicrin also showed cytostatic activity on HeLa cells ${ }^{[4,41,55]}$. There is no data on cytotoxic effect of solstitialin A-3, 13 diacetate, whereas it is known that solstitialin monoacetate has a high cytotoxic activity ${ }^{[54]}$. Elemacarmanin, isolated from Saussurea deltoideam, showed no cytotoxic activity against three cancer cell lines A549, Hela and SMMC-7721 ${ }^{[60]}$. Onopordopicrin showed cytotoxic activity on the human epidermoid carcinoma cell line $\mathrm{KB}^{[61]}$.

A number of epidemiological studies have been conducted to prove the protective effect of flavonoids against cancer, while some of the flavonoids, found also in Centaurea species, were connected with good cytotoxic activity ${ }^{[47,62,63]}$. The inhibition of tumor promotion by flavonoids may involve molecular mechanism of pro-oxidant process via inhibiting xanthine oxidase, COX or LOX55

This article is protected by copyright. All rights reserved. 
${ }^{\text {[63] }}$. Luteolin has been shown to penetrate into human skin, making it also a candidate for the prevention and treatment of skin cancer ${ }^{[64]}$. Some studies showed that luteolin and kaempferol derivatives exhibit cytotoxic activity ${ }^{[62,63]}$. Patulitrin showed growth inhibitory effect against HeLa cells ${ }^{[65]}$.

\section{Conclusions}

Centaurea ragusina flower and herba AE showed good cytotoxic activity against human bladder (T24) and human glioblastomma (A1235) cancer cell lines. Apparent cytotoxic activity of tested $C$. ragusina $\mathrm{AE}$ can be connected with chemical composition of both tested extracts. Some of the chemical compounds detected in the studies AE are already known on their cytotoxic properties. Centaurea ragusina $\mathrm{AE}$ represents a valuable source of sesquiterpene lactones and flavonoids, which anticancer activity has been reported in numerous studies. Hence, the preliminary cytotoxic activity results deserve further investigation in order to elucidate the specific compounds, or their combinations, responsible for the cytotoxic activity.

\section{Experimental section}

\section{Plant material and preparation of aqueous extracts}

The plant material of $C$. ragusina endemic species was collected in July in coastal habitats of island of Vis, Croatia. Plant was identified by a botanist and voucher specimens were deposited at the Department of Biochemistry, Faculty of Chemistry and Technology, Split, Croatia, under a name Cent_ragusina_Vis. Plant material was air dried at a room temperature. An AE from flower and herba dried plant material were prepared separately. Plant material of $15 \mathrm{~g}$ was dissolved in $0.15 \mathrm{~L}$ of hot distilled water. Tea solution was filtered after $30 \mathrm{~min}$ and AE was subjected to water evaporation by a low vacuum using the rotary evaporator. Dried AE was dissolved in distilled water and kept in a fridge at a temperature of $-20^{\circ} \mathrm{C}$ for further assays.

This article is protected by copyright. All rights reserved. 


\section{Determination of $C$. ragusina extracts chemical composition}

The high-resolution liquid chromatography/photo-diode array/electrospray ionization/time of flight mass spectra (HPLC/PDA/ESI/TOF MS) was performed on a HPLC instrument (Agilent 1100 Series) equipped with an auto-sampler, using a LiCrospher 100 RP18e analytical column (5 $\mu \mathrm{m}$ particle size, $4.0 \mathrm{~mm} \times 250 \mathrm{~mm}$ ) and a PDA detector (DAD) coupled with a 6210 TOF LC/MS system (Agilent Technologies).

Crude extracts of endemic $C$. ragusina were dissolved in methanol to an approximate concentration of $5 \mathrm{~g} / \mathrm{L}$. The HPLC/PDA/ESI/TOF MS analyses were performed under the following conditions: the mobile phase consisted of water containing $0.2 \%$ formic acid (A) and acetonitrile (B). A gradient program was used as follows: 0-0.5 min, 4 \% B; 0.5-40 min, 4-50 \% - $95 \%$ B; 40-45 min, 50-60 \% B; 45-60 min, 60-95 \% B; 60-68 min, $95 \%$ B; 68-70 min, 95-5 \% B, 70-80 min, 4\% B. The flow rate of the mobile phase was $0.8 \mathrm{~mL} / \mathrm{min}$, the column temperature was kept at $30{ }^{\circ} \mathrm{C}$ and the injection volume was $10 \mu \mathrm{L}$. UV spectral data from all detected peaks were accumulated in the range of 190$450 \mathrm{~nm}$ and chromatograms were recorded at $260 \mathrm{~nm}$. MS data were collected by applying the following parameters: ionization, negative ESI capillary voltage $4000 \mathrm{~V}$, gas temperature $350{ }^{\circ} \mathrm{C}$, drying gas $12 \mathrm{~L} / \mathrm{min}$, nebulizer pressure 45 psi*, fragmentor voltage $70 \mathrm{~V}$, mass range $100-1500 \mathrm{~m} / \mathrm{z}$. MassHunter Workstation software was used for data acquisition and processing.

Exact mass measurements of pseudomolecular ions of the analytes was performed with a time-offlight (TOF) mass spectrometer operating in the negative polarity mode, which enabled the determination of the molecular formula of most of the constituents. Chemical compounds in extracts have been tentatively identified by comparison of their spectroscopic data with literature records.

\section{Biological activity}

\section{Human cancer cell lines}

T24 bladder cancer cell line and A1235 glioblastoma cell line were grown at $37{ }^{\circ} \mathrm{C}$ in a humidified incubator and $5 \% \mathrm{CO}_{2}$ in Dulbecco's Modified Eagle Medium (DMEM, EuroClone, Milano, Italy) containing $10 \%$ fetal bovine serum and $1 \%$ antibiotics (Penicillin Streptomycin, EuroClone, Milano, Italy).

This article is protected by copyright. All rights reserved. 


\section{Cytotoxic activity assay}

Cell viability was determined using the tetrazolium salt (3-[4,5-dimethylthiazol-2-yl]-2,5-diphenyl tetrazolium bromide; MTT Sigma-Aldrich) in reduction MTT assay ${ }^{[66]}$. An equal number of cells was seeded into the wells of 96-well plate and allowed to attach overnight. Cells were afterward treated with flower and herba $\mathrm{AE}(100 \mu \mathrm{L})$, in triplicate concentrations of $0.5 \mathrm{~g} / \mathrm{L} ; 1 \mathrm{~g} / \mathrm{L} ; 2 \mathrm{~g} / \mathrm{L}$, in growing media, for $4 \mathrm{~h}, 24 \mathrm{~h}, 48 \mathrm{~h}$ and $72 \mathrm{~h}$. Following treatment, cells were incubated with $0.5 \mathrm{~g} / \mathrm{L} \mathrm{MTT} \mathrm{in}$ growing media for $1 \mathrm{~h}$ after media was removed cells were treated with DMSO (Sigma-Aldrich). Absorbance was measured at $570 \mathrm{~nm}$ (signal) and $690 \mathrm{~nm}$ (background).

\section{Flow cytometric analysis}

An equal number of cells were seeded in 6 -well plates and treated $100 \mu \mathrm{L}$ with $1 \mathrm{~g} / \mathrm{L}$ flower and herba $A E$ analyzed for apoptosis after $48 \mathrm{~h}$ treatment. After this treatment the cells were treated with trypsin, washed with PBS (phosphate buffer saline); suspended in $100 \mu \mathrm{L}$ of the binding buffer containing $5 \mu \mathrm{L}$ Annexin-V-FITC and/or $5 \mu \mathrm{L}$ of propidium iodide (PI) (Annexin-V-FITC Apoptosis Detection Kit I, BD Biosciences, San Jose, CA, USA) and incubated for $15 \mathrm{~min}$ at room temperature in the dark. The amount of apoptotic cells were analyzed using the flow cytometry (BD Accuri C6, BD Biosciences) and FlowLogic Software. The viability of cells was expressed in percent (\%) as the ratio of the absorbance of cells treated with $\mathrm{AE}$ and the absorbance of non-treated cells multiplied with 100. Results were presented as mean value \pm SD.

\section{Acknowledgement}

This work was supported by the Croatian Science Foundation [IP-2014-09-6897]. We thank our botanist dr. sc. Mirko Ruščić for determination of botanical material.

This article is protected by copyright. All rights reserved. 


\section{References}

[1] D. J. Newman, G. M. Cragg, 'Natural products as sources of new drugs over the 30 years from 1981 to 2010', J. Nat. Prod. 2012, 75, 311-335.

[2] L. Reddy, B. Odhav, K. D. Bhoola, 'Natural products for cancer prevention: a global perspective', Pharmacol. Ther. 2003, 99, 1-13.

[3] B. A. Weaver, 'How Taxol/paclitaxel kills cancer cells', Mol. Biol. Cell 2014, 25, 2677-2681.

[4] A. M. Beltagy, 'Chemical composition and cytotoxic activity of Centaurea scoparea Sieb against four human cell lines', Journal of Pharmaceutical Science and Research 2015, 7, 103107.

[5] S. B. Erel, C. Karaalp, E. Bedir, H. Kaehlig, S. Glasl, S. Khan, L. Krenn, 'Secondary metabolites of Centaurea calolepis and evaluation of cnicin for anti-inflammatory, antioxidant, and cytotoxic activities', Pharm. Biol. 2011, 49, 840-849.

[6] O. Kenny, T. J. Smyth, D. Walsh, C. T. Kelleher, C. M. Hewage, N. P. Brunton, 'Investigating the potential of under-utilised plants from the Asteraceae family as a source of natural antimicrobial and antioxidant extracts', Food Chem. 2014, 161, 79-86.

[7] S. M. F. Bessada, J. C. M. Barreira, M. B. P. P. Oliveira, 'Asteraceae species with most prominent bioactivity and their potential applications: A review', Industrial Crops and Products 2015, 76, 604-615.

[8] T. Garnatje, M. Á. Canela, S. Garcia, O. Hidalgo, J. Pellicer, I. Sánchez-Jiménez, S. SiljakYakovlev, D. Vitales, J. Vallès, 'GSAD: A genome size in the Asteraceae database', Cytometry Part A 2011, 79A, 401-404.

[9] S. Kovačić, Nikolić, T., 'Flora Jadranske obale i otoka', 2008.

[10] S. de Cortes, M. nchez-Mata, Tardi, J. o, Mediterranean wild edible plants : ethnobotany and food composition tables, Springer, New York, 2016.

[11] M. R. Gonzalez-Tejero, M. Casares-Porcel, C. P. Sanchez-Rojas, J. M. Ramiro-Gutierrez, J. Molero-Mesa, A. Pieroni, M. E. Giusti, E. Censorii, C. de Pasquale, A. Della, D. ParaskevaHadijchambi, A. Hadjichambis, Z. Houmani, M. El-Demerdash, M. El-Zayat, M. Hmamouchi, S. Eljohrig, 'Medicinal plants in the Mediterranean area: synthesis of the results of the project Rubia', J. Ethnopharmacol. 2008, 116, 341-357.

[12] S. Vitalini, F. Tome, G. Fico, 'Traditional uses of medicinal plants in Valvestino (Italy)', J. Ethnopharmacol. 2009, 121, 106-116.

[13] A. Khammar, S. Djeddi, ' Pharmacological and Biological Properties of some Centaurea Species', European Journal of Scientific Research 2012, 84, 398-416.

[14] S. B. Erel, C. Karaalp, E. Bedir, H. Kaehlig, S. Glasl, S. Khan, L. Krenn, 'Secondary metabolites of Centaurea calolepis and evaluation of cnicin for anti-inflammatory, antioxidant, and cytotoxic activities', Pharm. Biol. 2011, 49, 840-849.

This article is protected by copyright. All rights reserved. 
[15] Ş. Baykan Erel, S. Demir, F. Aydın Kose, P. Ballar, C. Karaalp, 'Cytotoxic properties of five Centaurea L. species from Anatolia', Planta Med. 2011, 77, PM149.

[16] B. H. Havsteen, 'The biochemistry and medical significance of the flavonoids', Pharmacol. Ther. 2002, 96, 67-202.

[17] T. Mishio, K. Takeda, T. Iwashina, 'Anthocyanins and other flavonoids as flower pigments from eleven Centaurea species', Nat. Prod. Commun. 2015, 10, 447-450.

[18] K. Alizadeh Astari, S. Baykan Erel, E. Bedir, C. Karaalp, 'Secondary Metabolites of Centaurea cadmea Boiss', Records of Natural Products 2013, 7, 242-244.

[19] M. Bruno, S. Bancheva, S. Rosselli, A. Maggio, 'Sesquiterpenoids in subtribe Centaureinae (Cass.) Dumort (tribe Cardueae, Asteraceae): distribution, (13)C NMR spectral data and biological properties', Phytochemistry 2013, 95, 19-93.

[20] M. L. Cardona, I. Fernández, J. R. Pedro, B. Pérez, 'Sesquiterpene lactones and flavonoids from Centaurea aspera', Phytochemistry 1991, 30, 2331-2333.

[21] H. Skaltsa, D. Lazari, C. Panagouleas, E. Georgiadou, B. Garcia, M. Sokovic, 'Sesquiterpene lactones from Centaurea thessala and Centaurea attica. Antifungal activity', Phytochemistry 2000, 55, 903-908.

[22] J. Y. Cho, A. R. Kim, J. H. Jung, T. Chun, M. H. Rhee, E. S. Yoo, 'Cytotoxic and pro-apoptotic activities of cynaropicrin, a sesquiterpene lactone, on the viability of leukocyte cancer cell lines', Eur. J. Pharmacol. 2004, 492, 85-94.

[23] M. Bruno, S. Rosselli, A. Maggio, R. A. Raccuglia, K. F. Bastow, C. C. Wu, K. H. Lee, 'Cytotoxic activity of some natural and synthetic sesquiterpene lactones', Planta Med. 2005, 71, 11761178.

[24] O. Politeo, M. Skocibusic, I. Carev, F. Burcul, I. Jerkovic, M. Sarolic, M. Milos, 'Phytochemical profiles of volatile constituents from Centaurea ragusina leaves and flowers and their antimicrobial effects', Nat. Prod. Commun. 2012, 7, 1087-1090.

[25] V. Vujcic, S. R. Brkanac, M. R. Stojkovic, M. Ruscic, B. Pevalek-Kozlina, 'Antioxidant activity and polyphenol content of endemic plant species Centaurea ragusina L', Planta Med. 2015, 81, 1444-1445.

[26] M. d. I. L. Cádiz-Gurrea, S. Fernández-Arroyo, J. Joven, A. Segura-Carretero, 'Comprehensive characterization by UHPLC-ESI-Q-TOF-MS from an Eryngium bourgatii extract and their antioxidant and anti-inflammatory activities', Food Res. Int. 2013, 50, 197-204.

[27] C. Pereira, L. Barros, A. M. Carvalho, I. C. F. R. Ferreira, 'Use of UFLC-PDA for the analysis of organic acids in thirty-five species of food and medicinal plants', Food Analytical Methods 2013, 6, 1337-1344.

[28] Y.-J. Zhang, T. Tanaka, C.-R. Yang, I. Kouno, 'New Phenolic Constituents from the Fruit Juice of Phyllanthus emblica', Chem. Pharm. Bull. 2001, 49, 537-540.

This article is protected by copyright. All rights reserved. 
[29] D. N. Olennikov, N. I. Kashchenko, H. Schwabl, C. Vennos, C. Loepfe, 'New Mucic Acid Gallates from Phyllanthus emblica', Chem. Nat. Compd. 2015, 51, 666-670.

[30] I. M. Abu-Reidah, M. S. Ali-Shtayeh, R. M. Jamous, D. Arráez-Román, A. Segura-Carretero, 'HPLC-DAD-ESI-MS/MS screening of bioactive components from Rhus coriaria L. (Sumac) fruits', Food Chem. 2015, 166, 179-191.

[31] L. Pirvu, C. Bubueanu, M. Panteli, L. Petcu, D. Coprean, in Open Chemistry, Vol. 13, 2015.

[32] M. B. Hossain, D. K. Rai, N. P. Brunton, A. B. Martin-Diana, C. Barry-Ryan, 'Characterization of phenolic composition in Lamiaceae spices by LC-ESI-MS/MS', J. Agric. Food Chem. 2010, 58, 10576-10581.

[33] A. Djihane, B. Kenza, D. Ibrahim, G. Fatih, S. Djamel, B. Samir, B. Fadila, M. Ratiba, 'Phenolic Profile and Antioxidant Activity of Centaurea choulettiana Pomel (Asteraceae) Extracts', Combinatorial Chem. High Throughput Screening 2016, 19, 841-846.

[34] S. Demir, C. Karaalp, E. Bedir, 'Unusual sesquiterpenes from Centaurea athoa DC', Phytochemistry Letters 2016, 15, 245-250.

[35] G. J. Sotes, L. A. Cavieres, D. Montesinos, A. X. Pereira Coutinho, W. J. Peláez, S. M. M. Lopes, T. M. V. D. Pinho e Melo, 'Inter-regional variation on leaf surface defenses in native and nonnative Centaurea solstitialis plants', Biochem. Syst. Ecol. 2015, 62, 208-218.

[36] M. Shoeb, S. M. MacManus, M. Jaspars, J. Trevidu, L. Nahar, P. Kong-Thoo-Lin, S. D. Sarker, 'Montamine, a unique dimeric indole alkaloid, from the seeds of Centaurea montana (Asteraceae), and its in vitro cytotoxic activity against the $\mathrm{CaCo} 2$ colon cancer cells', Tetrahedron 2006, 62, 11172-11177.

[37] Z. F. K. Mahmoud, F.F.; Abdel Salam, N.A., 'Sesquiterpene lactones and flavonoids of Centaurea ragusina ssp. ragusina growing in Egypt. ', Egypt J. Pharm. Sci. 1986, 27, 283-289.

[38] M. K. R. Mabry T. J., Thomas M. B. , The Systematic Identification of Flavonoids Springer Science \& Business Media, New York, 1970.

[39] C. Formisano, D. Rigano, F. Senatore, S. Bancheva, A. Maggio, S. Rosselli, M. Bruno, 'Flavonoids in Subtribe Centaureinae (Cass.) Dumort. (Tribe Cardueae, Asteraceae): Distribution and 13C-NMR Spectral Data', Chem. Biodivers. 2012, 9, 2096-2158.

[40] H. Skaltsa, D. Lazari, B. Garcia, R. Pedro José, M. Sokovic, T. Constantinidis, in Zeitschrift für Naturforschung C, Vol. 55, 2000, p. 534.

[41] A. K. Picman, 'Biological activities of sesquiterpene lactones', Biochem. Syst. Ecol. 1986, 14, 255-281.

[42] L. A. Richards, L. A. Dyer, M. L. Forister, A. M. Smilanich, C. D. Dodson, M. D. Leonard, C. S. Jeffrey, 'Phytochemical diversity drives plant-insect community diversity', Proc. Natl. Acad. Sci. U. S. A. 2015, 112, 10973-10978.

This article is protected by copyright. All rights reserved. 
[43] A. E. Ross, A. Emadi, L. Marchionni, P. J. Hurley, B. W. Simons, E. M. Schaeffer, M. VuicaRoss, 'Dimeric naphthoquinones, a novel class of compounds with prostate cancer cytotoxicity', BJU Int. 2011, 108, 447-454.

[44] Y. Fan, N. Ge, X. Wang, W. Sun, R. Mao, W. Bu, C. J. Creighton, P. Zheng, S. Vasudevan, L. An, J. Yang, Y. J. Zhao, H. Zhang, X. N. Li, P. H. Rao, E. Leung, Y. J. Lu, J. W. Gray, R. Schiff, S. G. Hilsenbeck, C. K. Osborne, J. Yang, H. Zhang, 'Amplification and over-expression of MAP3K3 gene in human breast cancer promotes formation and survival of breast cancer cells', J. Pathol. 2014, 232, 75-86.

[45] A. F. Barrero, J. E. Oltra, I. Rodriguez, A. Barragan, D. G. Gravalos, P. Ruiz, 'Lactones from species of Centaurea. Cytotoxic and antimicrobial activities', Fitoterapia 1995, 66, 227-230.

[46] E. H. Kolli, F. León, F. Benayache, S. Estévez, J. Quintana, F. Estévez, I. Brouard, J. Bermejo, S. Benayache, 'Cytotoxic sesquiterpene lactones and other constituents of Centaurea omphalotricha', J. Braz. Chem. Soc. 2012, 23, 977-983.

[47] S. A. Ahmed, E. M. Kamel, 'Cytotoxic Activities of Flavonoids from Centaurea scoparia', The Scientific World Journal 2014, 2014, 7.

[48] P. Forgo, I. Zupko, J. Molnar, A. Vasas, G. Dombi, J. Hohmann, 'Bioactivity-guided isolation of antiproliferative compounds from Centaurea jacea L', Fitoterapia 2012, 83, 921-925.

[49] N. El-Najjar, S. Dakdouki, N. Darwiche, M. El-Sabban, N. A. Saliba, H. Gali-Muhtasib, 'Anticolon cancer effects of Salograviolide A isolated from Centaurea ainetensis', Oncol. Rep. 2008, 19, 897-904.

[50] B. Csapi, Z. Hajdu, I. Zupko, A. Berenyi, P. Forgo, P. Szabo, J. Hohmann, 'Bioactivity-guided isolation of antiproliferative compounds from Centaurea arenaria', Phytother. Res. 2010, 24, 1664-1669.

[51] A. Ghantous, H. Gali-Muhtasib, H. Vuorela, N. A. Saliba, N. Darwiche, 'What made sesquiterpene lactones reach cancer clinical trials?', Drug Discov. Today 2010, 15, 668-678.

[52] A. Ulubelen, S. Öksüz, 'Cytotoxic Flavones From Centaurea urvillei', J. Nat. Prod. 1982, 45, 373-373.

[53] R. Seghiri, O. Boumaza, R. Mekkiou, S. Benayache, P. Mosset, J. Quintana, F. Estévez, F. León, J. Bermejo, F. Benayache, 'A flavonoid with cytotoxic activity and other constituents from Centaurea africana', Phytochemistry Letters 2009, 2, 114-118.

[54] R. Arif, E. Kupeli, F. Ergun, 'The biological activity of Centaurea L. species', G.U. Journal of Science 2004, 17, 149-164.

[55] A. G. González, V. Darias, G. Alonso, E. Estevez, 'The Cytostatic Activity of the Chlorohyssopifolins, Chlorinated Sesquiterpene Lactones from Centaurea1', Planta Med. 1980, 40, 179-184.

This article is protected by copyright. All rights reserved. 
[56] P. M. Bork, M. L. Schmitz, M. Kuhnt, C. Escher, M. Heinrich, 'Sesquiterpene lactone containing Mexican Indian medicinal plants and pure sesquiterpene lactones as potent inhibitors of transcription factor NF-KB', FEBS Lett. 1997, 402, 85-90.

[57] E. Koukoulitsa, H. Skaltsa, A. Karioti, C. Demetzos, K. Dimas, 'Bioactive Sesquiterpene Lactones from Centaurea Species and their Cytotoxic/Cytostatic Activity Against Human Cell Lines in vitro', Planta Med. 2002, 68, 649-652.

[58] M. Rao, T. Zin, M. Abdurazak, B. A. Ahmad, Chemistry and pharmacology of syringin, a novel bioglycoside: A review, Innovare Academic Science, 2015.

[59] N. Lall, N. Kishore, B. Binneman, D. Twilley, M. van de Venter, D. du Plessis-Stoman, G. Boukes, A. Hussein, 'Cytotoxicity of syringin and 4-methoxycinnamyl alcohol isolated from Foeniculum vulgare on selected human cell lines', Nat. Prod. Res. 2015, 29, 1752-1756.

[60] J.-J. Xu, H.-Q. Huang, G.-Z. Zeng, N.-H. Tan, 'Cytotoxic sesquiterpenes and lignans from Saussurea deltoidea', Fitoterapia 2012, 83, 1125-1130.

[61] G. Lonergan, G. Agelis, J. Hondrelis, J. Matsouka, L. K. Larsen, F. R. Caplan, 'Isolation, nmr studies, and biological activities of onopordopicrin from Centaurea sonchzfolza', J. Nat. Prod. 1992, 55, 225-228.

[62] P. Batra, A. K. Sharma, 'Anti-cancer potential of flavonoids: recent trends and future perspectives', 3 Biotech 2013, 3, 439-459.

[63] M. K. Chahar, N. Sharma, M. P. Dobhal, Y. C. Joshi, 'Flavonoids: A versatile source of anticancer drugs', Pharmacogn Rev. 2011, 5, 1-12.

[64] G. Seelinger, I. Merfort, U. Wolfle, C. M. Schempp, 'Anti-carcinogenic effects of the flavonoid luteolin', Molecules 2008, 13, 2628-2651.

[65] M. Kashif, S. Bano, S. Naqvi, S. Faizi, Lubna, M. Ahmed Mesaik, K. S. Azeemi, A. D. Farooq, 'Cytotoxic and antioxidant properties of phenolic compounds from Tagetes patula flower', Pharm. Biol. 2015, 53, 672-681.

[66] R. F. Hussain, A. M. Nouri, R. T. Oliver, 'A new approach for measurement of cytotoxicity using colorimetric assay', J. Immunol. Methods 1993, 160, 89-96.

This article is protected by copyright. All rights reserved. 